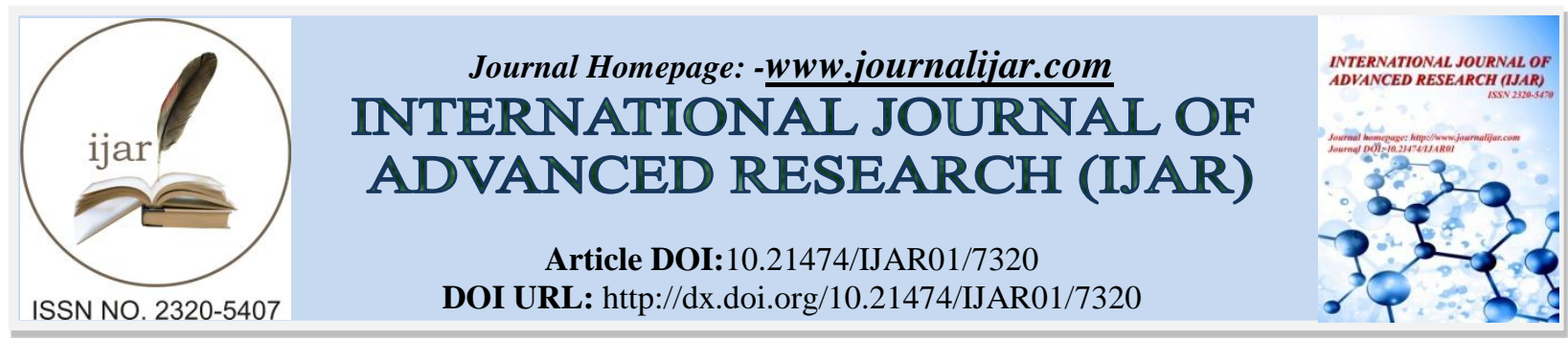

RESEARCH ARTICLE

\title{
DESIGN AND PERFORMANCE TEST OF APPROPRIATE ON-FARM COMPOSTING PACKAGE FOR SMALL FARMERS.
}

\author{
Hariadi $^{1}$, Yuli Suharnoto ${ }^{1}$ and Arief Sabdo Yuwono ${ }^{1}$. \\ Department of Civil and Environmental Engineering, Bogor Agricultural University (IPB), Campus IPB Dramaga, \\ PO Box 220 Bogor, 16002 Indonesia.
}

\section{Manuscript Info}

Manuscript History

Received: 19 April 2018

Final Accepted: 21 May 2018

Published: June 2018

Keywords:-

Composting, on-farm composting package, small farmers, quality standards

\begin{abstract}
In Indonesia, the active participation of farmers is fundamental to gain the multiple benefits of organic waste treatment via composting. Currently, small farmer involvement in composting practice has still low because of limited access to appropriate technologies. Minimum supply of appropriate facility increased the probability of ineffective organic waste treatment. The main aim of this research is to create appropriate on-farm composting package for small farmers by adopting NOL (non-odorous and low maintenance) principles in the whole composting process with minimum input of raw materials. The composting package maximizes goat housing with raised slatted floor function to become the major device with composting bin as a complement. The research showed that composting can be done with the minimum input of raw materials and maintenance. Overall, the majority of nutrient content of the composting products complied national quality standard [SNI 19-7030-2004] and decree of agricultural minister [Permentan No. 70/2011] so that it could be applied safely for the agricultural land especially for the horticultural plant. Therefore, this package is highly recommended for small farmers to assist composting practice with effective and efficient ways in developing countries.
\end{abstract}

Copy Right, IJAR, 2018,. All rights reserved.

\section{Introduction:-}

The total population of Indonesia is projected to reach 265 million by 2018 (BPS 2013) and with average waste generation rate $0.79 \mathrm{~kg} \mathrm{cap}^{-1} \mathrm{day}^{-1}$ (Hoornweg and Bhada-Tata, 2012), and the total waste produced is 209350 tons day $^{-1}$. The Ministry of Environment reported that the percentage of waste composition consist of: organic waste $60 \%$ (125 610 tons day ${ }^{-1}$ ), paper 9\% (18 842 tons day ${ }^{-1}$ ), plastic 14\% (29 309 tons day $^{-1}$ ), metal 4.3\% (9 002 tons day $^{-1}$ ), rubber 5.5\% ( 11514 tons day ${ }^{-1}$ ) and others $7.2 \%\left(15073\right.$ tons day $\left.{ }^{-1}\right)$, respectively (KKBPRI, 2015). The population growth is directly proportional to the increasing of waste generation in developing countries (Karak et al., 2012). Badan Pusat Statistik (BPS), the government's statistics agency stated that the population of Indonesia is estimated to exceed 285 million by 2025 and exceed 306 million by 2035 (BPS, 2013). Admittedly, proper waste management is urgently needed, since trend of the population growth rate has impacted on waste generation.

Previous studied, Dangi et al., (2011) pointed out that the waste composition became a fundamental consideration in determining appropriate treatment for waste processing. Similarly, Menikpura et al., (2013) emphasized that waste 
management practices -referred to integrated solid waste management (ISWM) - based on waste composition is effective to rise up savings greenhouse gaseous emissions. As a developing and agrarian country, composting strategy is the most compatible solution to resolve organic fraction of waste in Indonesia. Recently, the treatment methods comprised open dumping 60\%, composting 15\%, landfill 10\%, incineration 2\%, and others 13\% (Ngoc and Schnitzer, 2009) as well as the potential for irresponsible treatment like burnt $4.8 \%$ and disposed to river $2.9 \%$ (Meidiana and Gamse, 2010). Organic waste processed with composting only 18842 tons day $^{-1}$ of the total 125610 tons day $^{-1}$, while the remaining with open dumping and landfill have been notorious lead to serious environmental risks (Filho et al., 2016). Therefore, composting practice that environmentally friendly need special attention.

Composting, valuable treatment for organic waste, plays a significant role in sustainable agriculture and improve the quality of the environment. Most importantly, the final product can be used for multiple purposes such as fertilizer, soil amendment, plant nutrition, and growing media (Jara-Samaniego et al., 2017). Composting is top priority to overcome the organic waste problem in zero waste management (Zaman, 2014) to achieve optimum consumption without causing the negative impact for environment and human health (Song et al., 2014).

Composting practice is a suitable and increasingly viable treatment to implement in developing countries, as they possess abundant and various organic waste resources as raw material. The previous study about LCA (life cycle assessment) has evidenced that composting has many environmental advantages like nutrient supply for soil-plant and carbon sequestration (Martinez-Blanco et al., 2013), so highly recommended for developing countries (Harir et al., 2015; Ince et al., 2015). Implementation of composting product in the long term has proven the positive effect on chemical fertility of soil and sequestration of carbon (Aranda et al., 2015).

Successful and sustainable organic waste processing with composting depends on the contribution from citizens to adopt and perform composting mainly farmers; yet the reliability of infrastructure system must be improved. Big sizing composting technologies or plants with centralized approach are often unsuitable because of high operating cost, waste collection and separation problem (Hoornweg and Bhada-Tata, 2012; MacRae and Rodic, 2015), also need professional labor or organization (Azim et al., 2017).

The significant time and maintenance to manage the composting process such as frequent turning prevented farmers to perform their own composting practice because they have primary activities (Viaene et al., 2016). Furthermore, the price of composting product on the market is very low, around Rp1 $200-1700$ (US $\$ 1=\mathrm{Rp} 13500$ in October 2017). Decentralized system has been proposed to handling waste generation (Rothenberger et al., 2006; Medina, 2010; Dhokhikah and Trihadiningrum, 2012) with considering optimal scale of the plant (Misra et al., 2003; Pandyaswargo and Premakumara, 2014; Kajiya et al., 2015) to contribute to the realization of zero waste management (Zaman, 2015).

The small farmers role is vital both as producers and users of compost product. As the producer, the farmers produce their composting product to minimize input from outside especially mineral fertilizer, whereas as the consumer, the product can be directly applied into the farmland. Small farmers hold $<2$ hectares of land (von Braun, 2004; Lowder et al., 2016) with $4-6$ small ruminant (goats and sheep) (Davendra, 1993). According to the Indonesian agriculture census report of 2013, the number of farming households who hold $<2$ hectares reached 22.90 million out of a total 26.14 million (ST, 2013).

Budisatria et al., (2010) stated small farmers who make livestock as secondary activity on farms can keep the maximum number of goats or sheep at any time is 5 with average working hours of $3.8 \mathrm{~h} \mathrm{~d}^{-1}$. Therefore, supporting appropriate composting technologies for the farmers are such essential that complexity of making compost can be minimized to increase participation of them (Supaporn et al., 2013). Furthermore, it is expected to be able to improve economic feasibility associated with agronomic value (Fan et al., 2016).

The objectives of this research were as followings:

1. To design and develop appropriate on-farm composting package for small farmers.

2. To conduct composting by minimizing the input of raw materials and maintenance.

3. To test the compliance of the resulted compost according to the regulation standard in Indonesia: national quality standard [SNI 19-7030-2004] and decree of agricultural minister [Permentan No. 70/2011]. 


\section{Research methods:-}

Target person in this research is small farmers who main activities are agriculture while raising or fattening goats are only secondary one. It used goat housing with raised slatted floor. The farmer offered feed ad libitum twice a day, in the morning and afternoon. All of research procedures are depicted schematically in Figure 1.

\section{Finding effective composting ways:-}

Composting process was conducted under two conditions: aerobic and semi-anaerobic. Sample composts under aerobic condition are A, B, and C. The sample A and B comprised of 3 samples: A1, A2, A3 and B1, B2, B3, respectively, while $\mathrm{C}$ just only have 1 sample. On the semi-anaerobic, it is only sample compost $\mathrm{D}$. The material inputs are shown in Table 1.

The aerobic composting devices comprise goat housing with raised slatted floor and composting bins from bamboo and wood with a volume of approximately $0.12 \mathrm{~m}^{3}$ (length $\times$ width $\times$ height $=1 \mathrm{~m} \times 0.4 \mathrm{~m} \times 0.3 \mathrm{~m}$ ). Sample compost $\mathrm{A}$ and $\mathrm{B}$ are with composting bin but for $\mathrm{C}$ is without. The composting package is shown in Figure 2 .

Table 1:-The material inputs of aerobic and semi-anaerobic composting

\begin{tabular}{|l|c|c|}
\hline \multirow{2}{*}{ Sample compost } & Raw materials & Material inputs \\
\cline { 2 - 3 } & goat manure, sawdust & None \\
\hline Compost A & goat manure, uneaten grasses & None \\
\hline Compost B & goat manure, sawdust, uneaten grasses & None \\
\hline Compost C & solid goat manure, litter & Molasses, EM4 $^{\text {b }}$ \\
\hline Compost D &
\end{tabular}

${ }^{\mathrm{a}}$ Mixture chicken manure and rice husk ${ }^{\mathrm{b}}$ effective microorganism 4 
Figure 1:-Research procedure

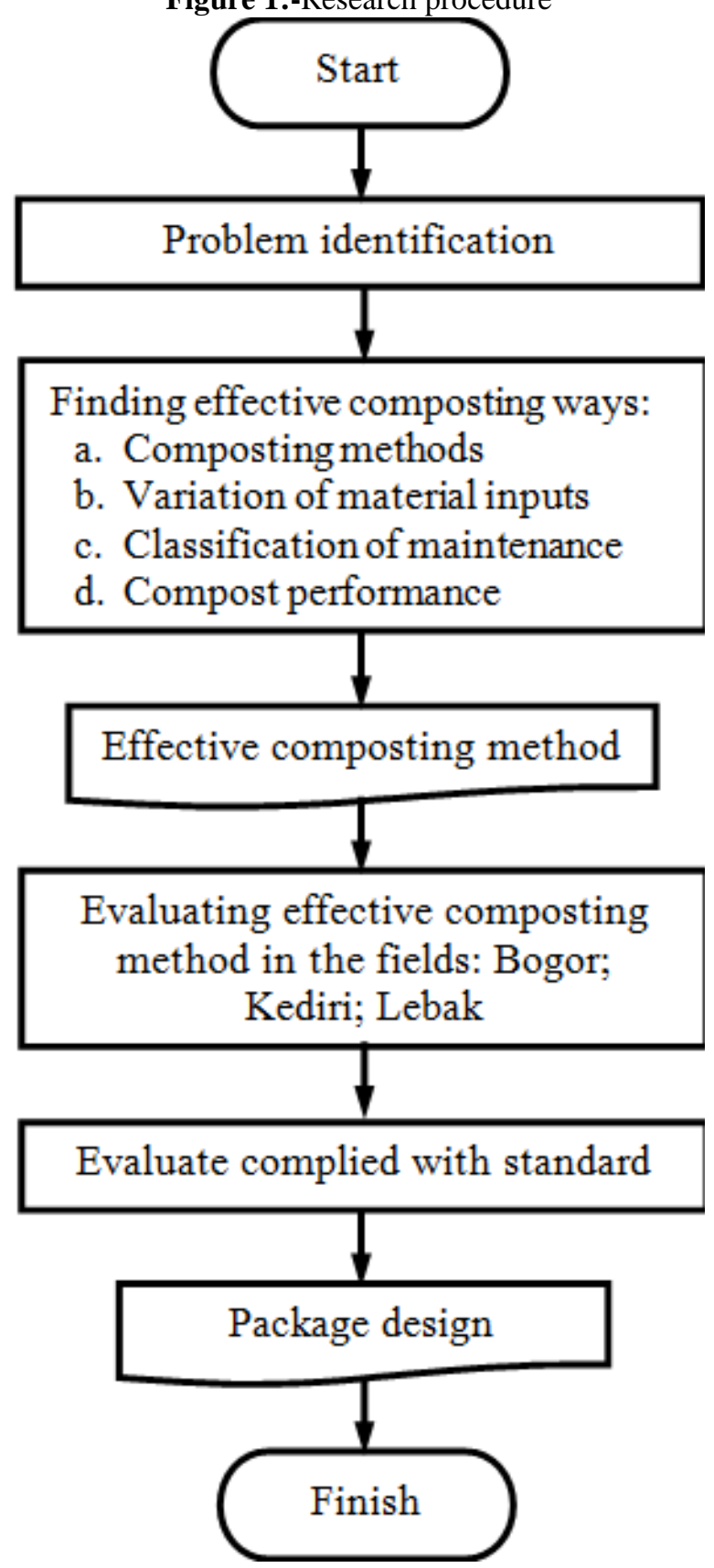




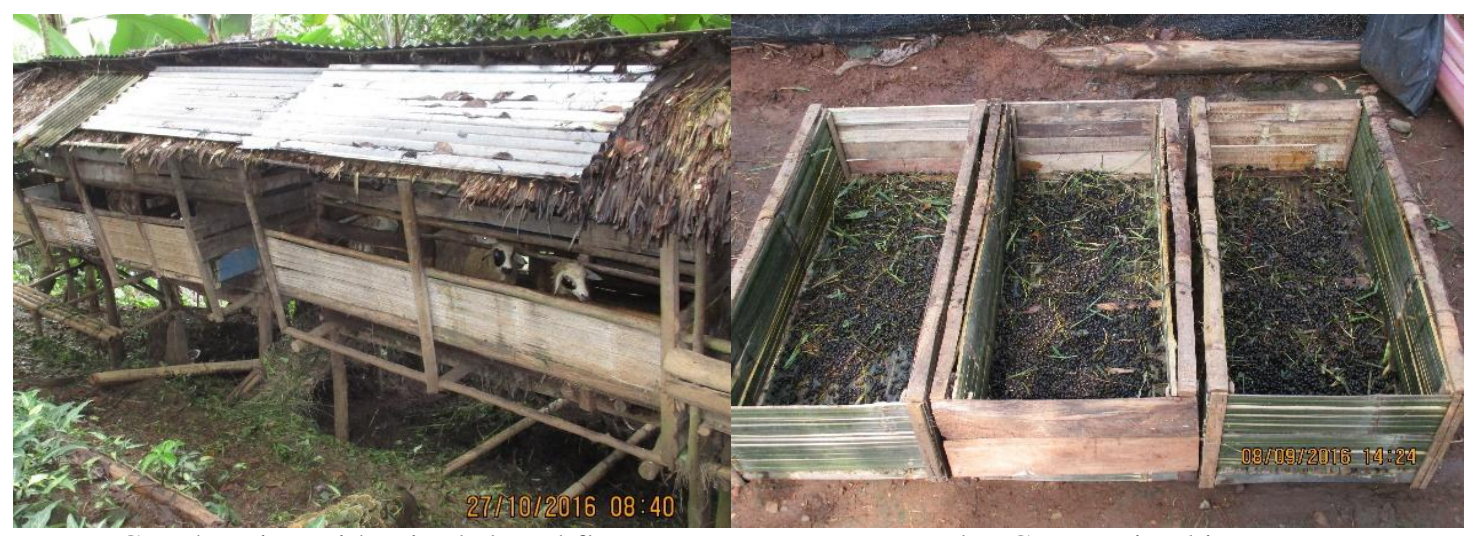

a. Goat housing with raised slatted floor

b. Composting bins

Figure 2:-Composting package device

Aerobic composting was carried out with the natural aerated static pile. Its process took place under the goat housing and then continued at maturation place. The initial process occurred underneath the housing during 14-30 days to create the layer of materials until the composting bins full, while urine from goats maintained moisture content to substitute rewetting maintenance. Later, the bins was moved out from the housing to maturation place and continued the process until maturity phase. Duration of the composting was 120 days from beginning to maturation phase. The aerobic scheme and description are shown in Figure 3 and Table 2.

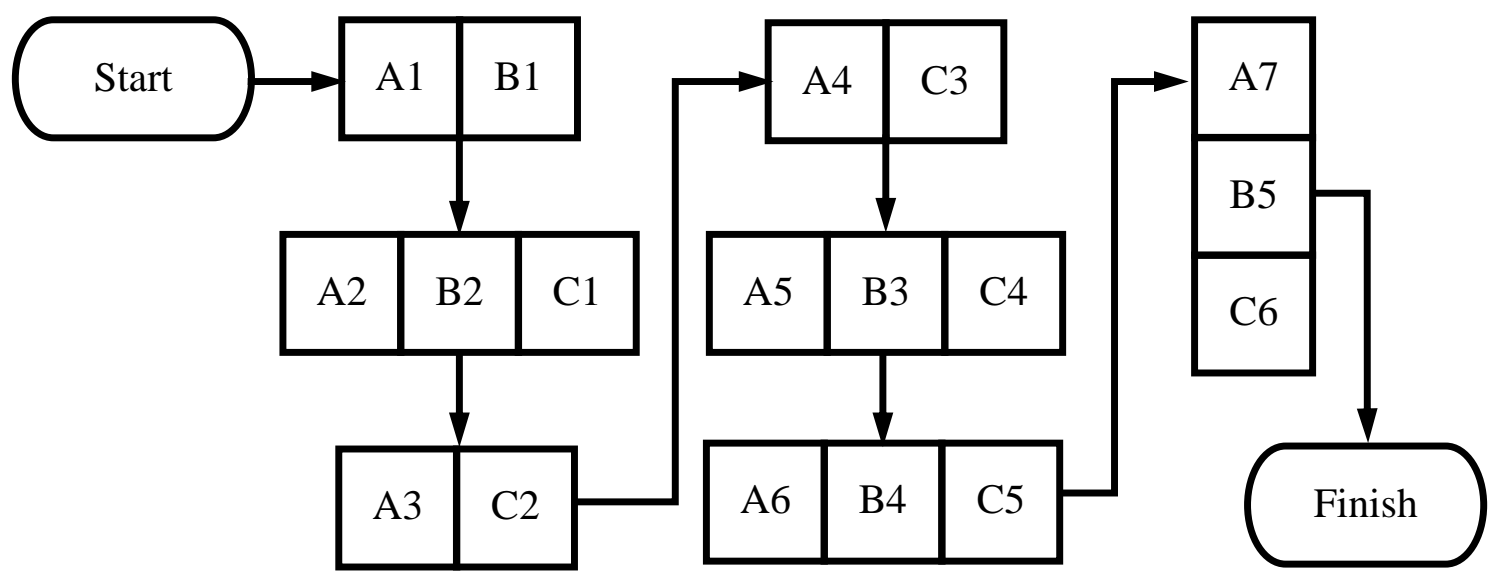

Figure 3:-Scheme of aerobic composting

Table 2:-Description of aerobic composting scheme

Code

Aerobic composting procedures

Underneath the goat housing

\begin{tabular}{|}
\hline \hline A1 & B1 & & Composting bins under the housing \\
\hline A2 & B2 & & The manure and uneaten grasses for B2 dropped and then filled into the bins \\
\hline & & C1 & The manure and uneaten grasses dropped on the ground under the housing \\
\hline A3 & & C2 & Sawdust is added into composting bin as the second layer \\
\hline A4 & & & Multiple layer between the manure and sawdust until the bins full \\
\hline & & C3 & The same as A4 but with addition uneaten grasses \\
\hline \\
\hline Out from the goat housing \\
\hline A5 & B3 & & The bins removed from under the housing \\
\hline & & C4 & The composting pile removed from under the housing \\
\hline A6 & B4 & C5 & The composting pile put in the maturation place \\
\hline A7 & B5 & C6 & The compost harvested \\
\hline
\end{tabular}


Semi-anaerobic composting was conducted on the ground. The tools used in this composting included tarpaulin, pail, and chimney. Raw materials in the form of goat manure only used solid manure without liquid manure (urine). The age of solid manure used was about 2 weeks (not fresh manure). Litter was obtained from poultry farm around the research site. The total duration of the semi-anaerobic composting was 14 days. The semi-anaerobic scheme and description are shown in Figure 4 and Table 3. Composition details of materials input as followings:

Raw materials: solid goat manure and charcoal for each $45 \mathrm{~L}$.

Mixture of liquid aditive (EM4: molasses: water; $15 \mathrm{~mL}: 15 \mathrm{~mL}: 10000 \mathrm{~mL}$ ).

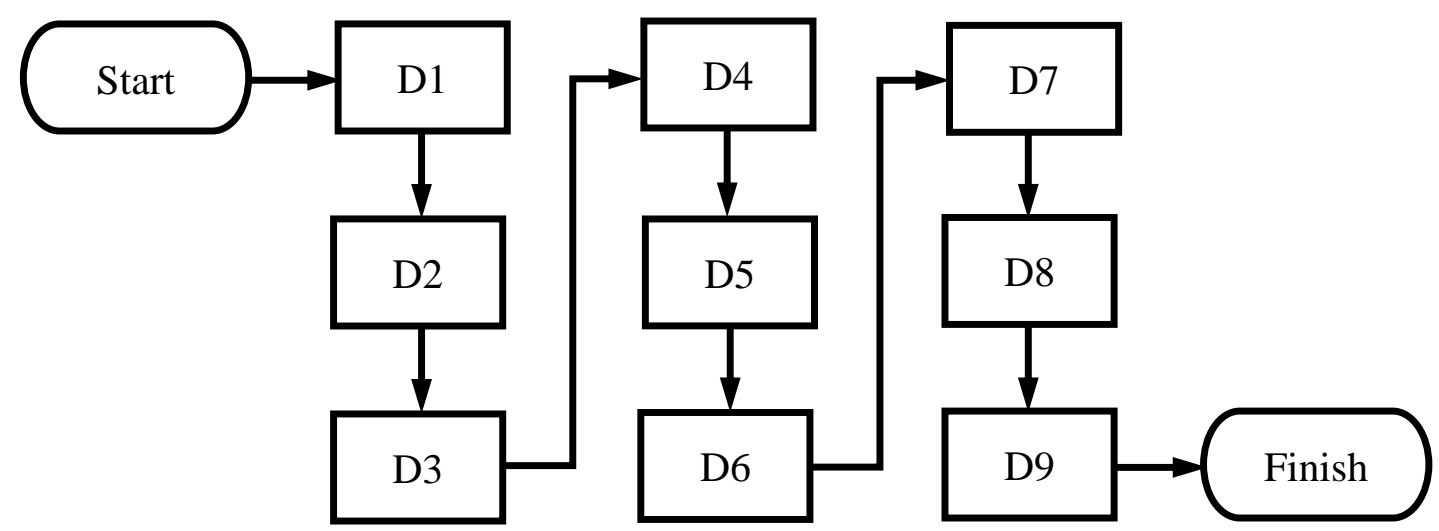

Figure 4:-Scheme of semi-anaerobic composting

Table 3:-Description of semi-anaerobic composting scheme

\begin{tabular}{|l|l|}
\hline Code & \multicolumn{1}{|c|}{ Semi-anaerobic composting procedures } \\
\hline D1 & Burning litter becomes charcoal \\
\hline D2 & Mixing liquid additive EM4, molasses, and water \\
\hline D3 & Mixing raw materials; goat manure and the charcoal \\
\hline D4 & Mixing raw materials and liquid additive \\
\hline D5 & Making high pile $\pm 20 \mathrm{~cm}$ \\
\hline D6 & Close pile with tarpaulin \\
\hline D7 & Monitor temperature every morning \\
\hline D8 & Reducing the height of pile, if $>40^{0} \mathrm{C}$ minimize the high of pile \\
\hline D9 & The compost harvested \\
\hline
\end{tabular}

Evaluating effective composting method in the fields:-

Evaluating effective composting methods were undertaken using aerobic condition in different sites (Bogor district, West Java; Kediri district; East java; Lebak district, Banten). The material inputs consisted of goat manure and sawdust. Sawdust was obtained from local sawmill around the research site. Sample compost X, Y, and Z have each 3 samples are X1, X2, X3; Y1, Y2, Y3; and Z1, Z2, Z3, respectively. Composting procedure followed Sample A procedure (Figure 3 and Table 2).

Table 4:-Material inputs of composting in the fields

\begin{tabular}{|l|l|l|c|}
\hline Sample compost & \multicolumn{1}{|c|}{ Site } & \multicolumn{2}{|c|}{ Material inputs } \\
\cline { 3 - 4 } & & \multicolumn{1}{|c|}{ Raw materials } & Additive \\
\hline Compost X & Bogor & goat manure, sawdust & None \\
\hline Compost Y & Kediri & goat manure, sawdust & None \\
\hline Compost Z & Lebak & goat manure, sawdust & \\
\hline
\end{tabular}

Characteristic of raw materials:-

Goat manure contains 5.06\% N, 0.67\% P, and 3.97\% K (Novien, 2004). Basically, animal manures like goat manure can improve soil properties with direct application; nevertheless, Bernal et al., (2009) summarised several reasons make composting the manures be an alternative one, i.e.: 
1. Reduction weeds (Kasirivu et al., 2011) and pathogens (Grewal et al., 2006)

2. Microbial stabilisation (Vinneras, 2013) and ease of storage, transport, and use

3. Reduction of mass and volume (Michel et al., 2004; Augustin and Rahman, 2010)

4. Removal and control of odours (Blazy et al., 2014)

5. Production of good quality fertilizer or substrate (Bernal et al., 2009)

When composting livestock manure particularly ruminant, using the bulking agents or dry matter like sawdust, rice husk, woodchips, and etc. is very needed (Leconte et al., 2011; Kajiya et al., 2015; Viaene et al., 2016) to prevent odor nuisance (Maeda et al., 2011; Chadwick et al., 2011). Bong et al., (2017) verified that decomposition process of composting as main contributor global warming potential and using bulking agent more helpful to mitigate it. Therefore, sawdust became additional raw materials in this composting practice.

Sawdust is one of the main waste of forestry sector that has not been optimally utilized in Indonesia, although some of them have been used as briquette and bag-log (mushroom growth media). It contains $0.24 \% \mathrm{~N}, 0.20 \% \mathrm{P}_{2} \mathrm{O}_{5}$, and $0.45 \% \mathrm{~K}_{2} \mathrm{O}$ (Wibowo, 1990). By 2016, production of processed timber reported that sawn timber $2.35 \mathrm{million}^{3}$ and plywood 0.98 million $\mathrm{m}^{3}$ (BPS, 2016), with sawdust production in volume about $9 \%$ of sawn timber and $2 \%$ of plywood (Purwanto, 2009). Besides, total sawdust production about 0.23 million $\mathrm{m}^{3}$ per year.

\section{Results and discussion:- Composting package:-}

Using goat housing with raised slatted floor optimized the housing function, so the small farmers just only required composting bins as additional equipment. Simple technological solution for the farmers with cost-effectiveness are necessary to develop this practice for the beneficial treatment of organic waste. Accordingly, combining the goat housing and bins are useful to reach the goal where the small farmers can provide device of the package. On the other hand, composting practice used on-farm system; hence, preventing the high operating, maintenance, and cost (Brito et al., 2012), as well as eliminating greenhouse gaseous from transportation of the raw materials (Menikpura et al., 2013).

\section{Composting methods:-}

Aerobic and semi-anaerobic composting were done to compare the number of inputs and maintenance. In order to the small farmer can perform composting, maintenance during the process was attempted to minimize so that major activities of farmers not disturb. The maintenances are various such as shredding raw materials, using bulking agent (Iqbal et al., 2010; Villar et al., 2016), adding microorganism (Awasthi et al., 2014), frequent turning and adding material (Getahun et al., 2012; Awasthi et al., 2014; Peev et al., 2017), water addition (El Kader et al., 2007), monitor temperature and control aeration rate (Das et al., 2011; Xiong et al., 2017). Reducing maintenance decreased complexity and pressure the cost, also preserve the practicability (Brito et al., 2012). In other side, selection of input materials can affect the composting cost, so the input should be obtained easily and adequately around the research site. The material inputs and classification of maintenances are shown in Table 5.

As can be seen in Table 5, raw materials for aerobic composting consist of $2-3$ mixture without additive, whereas semi-anaerobic composting need 4 inputs, raw materials and additive. Using additive helps speed up the decomposition process, but it is not recommended because generally small farmers have to buy to get it. Minimalize the input are expected to encourage the participation of the farmers in by using only waste that is available in the local area.

Composting animal manures like goat manure need bulking agent to minimize the potential for odour emissions; consequently, adding of bulking agent like sawdust (Sample A dan C) and rice husk (Sample D) is critical.

Despite its long maturity phase, aerobic composting is preferred over semi-anaerobic due to considering the number of maintenances. Burning litter, mixing and daily monitoring of temperature pile make it difficult for farmers, as well as litter is not available any time and limited. 
Table 5:-Material inputs and maintenance classification of composting

\begin{tabular}{|c|c|c|c|c|c|c|c|c|c|}
\hline \multirow[t]{2}{*}{ Materials input } & \multicolumn{4}{|c|}{ Compost sample } & \multirow[t]{2}{*}{ Maintenance } & \multicolumn{4}{|c|}{ Compost sample } \\
\hline & $\mathbf{A}$ & B & $\mathbf{C}$ & D & & $\mathbf{A}$ & B & $\mathbf{C}$ & D \\
\hline Raw materials & & & & & Shredder & - & - & - & - \\
\hline Goat manure & $\sqrt{ }$ & $\sqrt{ }$ & $\sqrt{ }$ & $\sqrt{ }$ & Frequent adding input & $\sqrt{ }$ & - & $\sqrt{ }$ & - \\
\hline Sawdust & $\sqrt{ }$ & - & $\sqrt{ }$ & - & Frequent turning & - & - & - & - \\
\hline Uneaten grasses & & $\sqrt{ }$ & $\sqrt{ }$ & - & Mixing & - & - & - & $\sqrt{ }$ \\
\hline \begin{tabular}{|l|} 
Litter \\
\end{tabular} & - & - & - & $\sqrt{ }$ & Rewetting & - & - & - & - \\
\hline Additive & & & & & Burning & - & - & - & $\sqrt{ }$ \\
\hline EM4 & - & - & - & $\sqrt{ }$ & Moving pile & $\sqrt{ }$ & $\sqrt{ }$ & $\sqrt{ }$ & - \\
\hline Molasses & - & - & - & $\sqrt{ }$ & Monitoring temperature & - & - & - & $\sqrt{ }$ \\
\hline Number of materials & & & & & Forced aeration & - & - & - & - \\
\hline 2 & $\sqrt{ }$ & $\sqrt{ }$ & - & - & Composting methods & & & & \\
\hline 3 & - & - & $\sqrt{ }$ & - & Aerobic & $\sqrt{ }$ & $\sqrt{ }$ & $\sqrt{ }$ & - \\
\hline 4 & - & - & - & $\sqrt{ }$ & Semi-anaerobic & - & - & - & $\sqrt{ }$ \\
\hline Function of input & & & & & Anaerobic & - & - & - & - \\
\hline Bulking agent & $\sqrt{ }$ & - & $\sqrt{ }$ & $\sqrt{ }$ & Duration of maturity & & & & \\
\hline Commercial activator & - & - & - & $\sqrt{ }$ & 14 days & - & - & - & $\sqrt{ }$ \\
\hline Bio-activator & $\sqrt{ }$ & $\sqrt{ }$ & $\sqrt{ }$ & $\sqrt{ }$ & 120 days & $\sqrt{ }$ & $\sqrt{ }$ & $\sqrt{ }$ & - \\
\hline
\end{tabular}

\section{Effective composting method:-}

Composting method used aerobic composting with low inputs and maintenance. As shown in Table 6, the input comprised 2 mixture with minimized maintenance. The frequent adding sawdust to make the layers of material and to maintain the homogeneity of the compost pile without mixing by the farmer.

Table 6:-Input materials and maintenance

\begin{tabular}{|l|l|}
\hline Input materials & Maintenance \\
\hline goat manure & Frequent adding the input of raw material (sawdust) \\
\hline Sawdust & Moving and turning pile to change position of the layers \\
\hline
\end{tabular}

The composting process adopted NOL (non-odorous and low maintenance) principles (Yuwono et al., 2016) and onfarm composting system (Viaene et al., 2016) based decentralized approach (Righi et al., 2013) to reach minimum cost (Brito et al., 2012). However, additional input of materials is possible during consideration of practicability the process like sample $\mathrm{C}$ with green waste one. By this package, it is expected that all potential waste which produce from goat breeding can be optimally managed into organic fertilizer, thus becoming one example of zero waste management application on small scale.

\section{Evaluation of compost performance:-}

The final composting products were analyzed to find out chemical properties macro- and micronutrients. Both are required to comply with standard of compost quality, SNI-19-7030-2004 and Permentan No. 70/2011. The standard provides assurance to farmer and another user that the composting product is safe, reliable, and high quality.

Table 7 shows the all value of total $\mathrm{N}+\mathrm{P}_{2} \mathrm{O}_{5}+\mathrm{K}_{2} \mathrm{O}$ for compost sample A (A1, A2, A3) did not comply Permentan No. 70/2011, for its value is still under minimum requirement. Additionally, Table 8 shows the sample $\mathrm{D}$ for $\mathrm{Cu}$ value $(300 \mathrm{ppm})$ exceeds the maximum limit. However, the quality of composting product can still improve physical properties of soil and have a favorable impact on the growth of the horticultural plant (Mylavarapu and Zinati, 2009).

To composting in the fields, several macronutrients did not comply the standard i.e. total $\mathrm{N}_{+}+\mathrm{P}_{2} \mathrm{O}_{5}+\mathrm{K}_{2} \mathrm{O}$ to sample $\mathrm{X} 1, \mathrm{Y} 2, \mathrm{Y} 3$ and $\mathrm{P}_{2} \mathrm{O}_{5}$ to sample $\mathrm{Y} 3$. Furthermore, especially for the sample $\mathrm{Z}$, all value of $\mathrm{P}_{2} \mathrm{O}_{5}$ and total $\mathrm{N}+\mathrm{P}_{2} \mathrm{O}_{5}+\mathrm{K}_{2} \mathrm{O}$ as well as $\mathrm{K}_{2} \mathrm{O}$ to $\mathrm{Z2}$, the nutrient content under the minimum standard as shown in Table 9. Based on composting performance test, it concluded that to go up the macronutrients of composting require additional input such as green waste which contains phosphorus. By contrast, Table 10 shows the micronutrients of the all samples complied the national quality standard. 
Table 7:-Macronutrients parameters and compliance of the sample A, B, C, and D

\begin{tabular}{|c|c|c|c|c|c|c|c|c|c|c|}
\hline \multirow[t]{2}{*}{ Parameters } & \multicolumn{8}{|c|}{ Compost samples } & \multicolumn{2}{|c|}{ Quality standard } \\
\hline & A1 & A2 & A3 & B1 & B2 & B3 & $\mathrm{C}$ & $\mathrm{D}$ & QS1 & QS2 \\
\hline \multicolumn{11}{|c|}{ Macronutrients (\%) } \\
\hline Organic C & 36 & 39 & 18 & 38 & 38 & 41 & 24 & 28 & $9.8-32$ & $\geq 15$ \\
\hline Nitrogen $(\mathrm{N})$ & 1.54 & 1.76 & 1.77 & 2.18 & 2.30 & 1.89 & 1.64 & 1.27 & $\geq 0.40$ & - \\
\hline $\mathrm{P}_{2} \mathrm{O}_{5}$ & 0.82 & 0.81 & 0.85 & 1.94 & 2.02 & 1.65 & 1.45 & 1.75 & $\geq 0.10$ & - \\
\hline $\mathrm{K}_{2} \mathrm{O}$ & 0.68 & 0.34 & 0.33 & 0.32 & 0.50 & 0.25 & 0.60 & 1.92 & $\geq 0.20$ & - \\
\hline $\mathrm{N}+\mathrm{P}_{2} \mathrm{O}_{5}+\mathrm{K}_{2} \mathrm{O}$ & 3 & 3 & 3 & 4 & 5 & 4 & 4 & 5 & - & $\geq 4$ \\
\hline \multicolumn{11}{|l|}{ Macronutrients } \\
\hline Organic C & QS2 & QS2 & QS1 & QS2 & QS2 & $\mathrm{QS2}$ & QS1 & QS1 & $9.8-32$ & $\geq 15$ \\
\hline Nitrogen $(\mathrm{N})$ & QS2 & QS2 & QS1 & QS1 & QS1 & QS1 & QS1 & QS1 & $\geq 0.40$ & - \\
\hline $\mathrm{P}_{2} \mathrm{O}_{5}$ & QS2 & QS2 & QS1 & QS1 & QS1 & QS1 & QS1 & QS1 & $\geq 0.10$ & - \\
\hline $\mathrm{K}_{2} \mathrm{O}$ & QS2 & QS2 & QS1 & QS1 & QS1 & QS1 & QS1 & QS1 & $\geq 0.20$ & - \\
\hline $\mathrm{N}+\mathrm{P}_{2} \mathrm{O}_{5}+\mathrm{K}_{2} \mathrm{O}$ & $*$ & $*$ & $*$ & QS2 & QS2 & QS2 & QS2 & QS2 & - & $\geq 4$ \\
\hline
\end{tabular}

QS1 = SNI 19-7030-2004 QS2 = Permentan No. 70/2011 * = did not meet quality standard

Table 8:-Micronutrients parameters and compliance of the sample A, B, C, and D

\section{Parameters}

Compost samples

\begin{tabular}{|c|c|c|c|c|c|c|c|c|c|c|}
\hline & A1 & A2 & A3 & B1 & B2 & B3 & $\mathrm{C}$ & D & QS1 & QS2 \\
\hline \multicolumn{11}{|c|}{ Micronutrients (ppm) } \\
\hline Available Fe & 249 & 191 & 204 & 196 & 191 & 107 & 237 & 18 & - & $\leq 500$ \\
\hline Total Fe & 10333 & 9534 & 17192 & 12130 & 13288 & 9263 & 19131 & 6094 & $\leq 20000$ & $\leq 9000$ \\
\hline $\mathrm{Zn}$ & 117 & 126 & 143 & 237 & 228 & 256 & 194 & 502 & $\leq 500$ & $\leq 5000$ \\
\hline $\mathrm{Cu}$ & 16 & 18 & 27 & 36 & 37 & 25 & 28 & 370 & $\leq 100$ & \\
\hline $\mathrm{Mn}$ & 699 & 711 & 1042 & 1289 & 1408 & 1016 & 1222 & 1305 & $\leq 1000$ & $\leq 5000$ \\
\hline \multicolumn{11}{|l|}{ Others } \\
\hline $\mathrm{C}: \mathrm{N}$ ratio & 23 & 22 & 10 & 17 & 16 & 22 & 15 & 22 & $10-20$ & $15-25$ \\
\hline $\mathrm{pH}$ & 7 & 7 & 7 & 7 & 8 & 7 & 7 & 8 & - & 4-9 \\
\hline \multicolumn{11}{|l|}{ Micronutrients } \\
\hline Available Fe & QS2 & QS2 & QS2 & QS2 & QS2 & QS2 & QS2 & QS2 & - & $\leq 500$ \\
\hline Total Fe & QS2 & QS2 & QS2 & QS2 & QS2 & QS2 & QS2 & QS1 & $\leq 20000$ & $\leq 9000$ \\
\hline $\mathrm{Zn}$ & QS1 & QS1 & QS1 & QS1 & QS1 & QS1 & QS1 & QS2 & $\leq 500$ & $\leq 5000$ \\
\hline $\mathrm{Cu}$ & QS1 & QS1 & QS1 & QS1 & QS1 & QS1 & QS1 & $*$ & $\leq 100$ & \\
\hline $\mathrm{Mn}$ & QS1 & QS1 & QS2 & QS2 & QS2 & QS2 & QS2 & QS2 & $\leq 1000$ & $\leq 5000$ \\
\hline \multicolumn{11}{|l|}{ Others } \\
\hline $\mathrm{C}: \mathrm{N}$ ratio & QS2 & QS2 & QS1 & QS1 & QS1 & QS1 & QS1 & QS2 & $10-20$ & $15-25$ \\
\hline $\mathrm{pH}$ & QS2 & QS2 & QS2 & QS2 & QS2 & QS2 & QS2 & QS2 & - & 4-9 \\
\hline
\end{tabular}

QS1 = SNI 19-7030-2004 QS2 = Permentan No. 70/2011 * = did not meet quality standard

$\rightarrow$ Insert Table 9 .

Table 9:-Macronutrients parameters and compliance of the final product in the fields

\begin{tabular}{|c|c|c|c|c|c|c|c|c|c|c|c|}
\hline \multirow[t]{2}{*}{ Parameters } & \multicolumn{3}{|c|}{ Bogor } & \multicolumn{3}{|c|}{ Kediri } & \multicolumn{3}{|c|}{ Lebak } & \multicolumn{2}{|c|}{ Standard } \\
\hline & $\mathrm{X} 1$ & $\mathrm{X} 2$ & X3 & Y1 & $\mathrm{Y} 2$ & Y3 & Z1 & $\mathrm{Z} 2$ & Z3 & QS1 & QS2 \\
\hline \multicolumn{12}{|c|}{ Macronutrients (\%) } \\
\hline Organic C & 46 & 41 & 46 & 27 & 30 & 22 & 33 & 39 & 38 & $9.8-32$ & $\geq 15$ \\
\hline Nitrogen $(\mathrm{N})$ & 2.35 & 3.67 & 3.11 & 1.34 & 1.10 & 1.45 & 2.71 & 2.62 & 1.80 & $\geq 0.40$ & - \\
\hline $\mathrm{P}_{2} \mathrm{O}_{5}$ & 0.56 & 0.85 & 0.94 & 1.29 & 1.05 & 0.02 & 0.03 & 0.00 & 0.02 & $\geq 0.10$ & - \\
\hline $\mathrm{K}_{2} \mathrm{O}$ & 0.47 & 0.75 & 0.40 & 1.55 & 0.58 & 1.26 & 0.23 & 0.16 & 0.21 & $\geq 0.20$ & - \\
\hline $\mathrm{N}+\mathrm{P}_{2} \mathrm{O}_{5}+\mathrm{K}_{2} \mathrm{O}$ & 3 & 5 & 4 & 4 & 3 & 3 & 3 & 3 & 2 & - & $\geq 4$ \\
\hline $\mathrm{Ca}$ & 0.88 & 1.11 & 1.55 & 1.79 & 1.27 & 1.73 & 0.46 & 0.70 & 0.36 & $\leq 25.50$ & - \\
\hline $\mathrm{Mg}$ & 0.61 & 0.59 & 0.54 & 0.55 & 0.39 & 0.46 & 0.28 & 0.27 & 0.24 & $\leq 0.60$ & - \\
\hline
\end{tabular}




\begin{tabular}{|l|c|l|l|l|l|c|c|c|c|r|r|}
\hline Organic C & QS2 & QS2 & QS2 & QS1 & QS1 & QS1 & QS2 & QS2 & QS2 & $9.8-32$ & $\geq 15$ \\
\hline Nitrogen (N) & QS1 & QS1 & QS1 & QS1 & QS1 & QS1 & QS1 & QS1 & QS1 & $\geq 0.40$ & - \\
\hline $\mathrm{P}_{2} \mathrm{O}_{5}$ & QS1 & QS1 & QS1 & QS1 & QS1 & $*$ & $*$ & $*$ & $*$ & $\geq 0.10$ & - \\
\hline $\mathrm{K}_{2} \mathrm{O}$ & QS1 & QS1 & QS1 & QS1 & QS1 & QS1 & QS1 & $*$ & QS1 & $\geq 0.20$ & - \\
\hline $\mathrm{N}+\mathrm{P}_{2} \mathrm{O}_{5}+\mathrm{K}_{2} \mathrm{O}$ & $*$ & QS2 & QS2 & QS2 & $*$ & $*$ & $*$ & $*$ & $*$ & - & $\geq 4$ \\
\hline $\mathrm{Ca}$ & QS1 & QS1 & QS1 & QS1 & QS1 & QS1 & QS1 & QS1 & QS1 & $\leq 25.50$ & - \\
\hline $\mathrm{Mg}$ & QS1 & QS1 & QS1 & QS1 & QS1 & QS1 & QS1 & QS1 & QS1 & $\leq 0.60$ & - \\
\hline
\end{tabular}

QS1 = SNI 19-7030-2004 QS2 = Permentan No. 70/2011 * = did not meet quality standard

Table 10:-Micronutrients parameters and compliance of the final product in the fields

\begin{tabular}{|c|c|c|c|c|c|c|c|c|c|c|c|}
\hline \multirow[t]{2}{*}{ Parameters } & \multicolumn{3}{|c|}{ Bogor } & \multicolumn{3}{|c|}{ Kediri } & \multicolumn{3}{|c|}{ Lebak } & \multicolumn{2}{|c|}{ Standard } \\
\hline & $\mathrm{X} 1$ & $\mathrm{X} 2$ & $\mathrm{X} 3$ & $\mathrm{Y} 1$ & $\mathrm{Y} 2$ & $\mathrm{Y} 3$ & $\mathrm{Z1}$ & $\mathrm{Z} 2$ & $\mathrm{Z3}$ & \begin{tabular}{l|l} 
QS1 & \\
\end{tabular} & QS2 \\
\hline \multicolumn{12}{|c|}{ Micronutrients (ppm) } \\
\hline Available Fe & 22 & 26 & 12 & 8 & 55 & 31 & 331 & 364 & 299 & & $\leq 500$ \\
\hline Total Fe & 8999 & 12156 & 2800 & 13105 & 10552 & 1198 & 3121 & 29 & 2389 & $\leq 20000$ & $\leq 9000$ \\
\hline $\mathrm{Zn}$ & 123 & 197 & 245 & 99 & 86 & 81 & 222 & 245 & 194 & $\leq 500$ & $\leq 5000$ \\
\hline $\mathrm{Cu}$ & 37 & 56 & 54 & 31 & 27 & 34 & 39 & 41 & 30 & $\leq 100$ & \\
\hline $\mathrm{Mn}$ & 1609 & 2967 & 2312 & 412 & 309 & 328 & 158 & 173 & 135 & $\leq 1000$ & $\leq 5000$ \\
\hline \multicolumn{12}{|l|}{ Others } \\
\hline C:N ratio & 19 & 11 & 15 & 20 & 27 & 15 & 12 & 15 & 21 & $10-20$ & $15-25$ \\
\hline $\mathrm{pH}$ & 7 & 7 & 7 & 8 & 8 & 8 & 7 & 7 & 7 & & 4-9 \\
\hline \multicolumn{12}{|l|}{ Micronutrients } \\
\hline Available Fe & QS2 & QS2 & QS2 & $\mathrm{QS} 2$ & QS2 & QS2 & QS2 & $\mathrm{QS} 2$ & QS2 & & $\leq 500$ \\
\hline Total Fe & QS2 & QS1 & QS2 & QS1 & QS1 & QS2 & QS2 & QS2 & QS2 & $\leq 20000$ & $\leq 9000$ \\
\hline $\mathrm{Zn}$ & QS1 & QS1 & QS1 & QS1 & QS1 & QS1 & QS1 & QS1 & QS1 & $\leq 500$ & $\leq 5000$ \\
\hline $\mathrm{Cu}$ & QS1 & QS1 & QS1 & QS1 & QS1 & QS1 & QS1 & QS1 & QS1 & $\leq 100$ & \\
\hline $\mathrm{Mn}$ & QS2 & QS2 & QS2 & $\mathrm{QS} 1$ & QS1 & QS1 & QS1 & QS1 & QS1 & $\leq 1000$ & $\leq 5000$ \\
\hline \multicolumn{12}{|l|}{ Others } \\
\hline C:N ratio & QS1 & QS1 & QS1 & QS1 & QS2 & QS1 & QS1 & QS1 & QS2 & $10-20$ & $15-25$ \\
\hline $\mathrm{pH}$ & QS2 & QS2 & QS2 & QS2 & QS2 & QS2 & QS2 & QS2 & QS2 & - & $4-9$ \\
\hline
\end{tabular}

QS1 = SNI 19-7030-2004 QS2 $=$ Permentan No. 70/2011 * $=$ did not meet quality standard
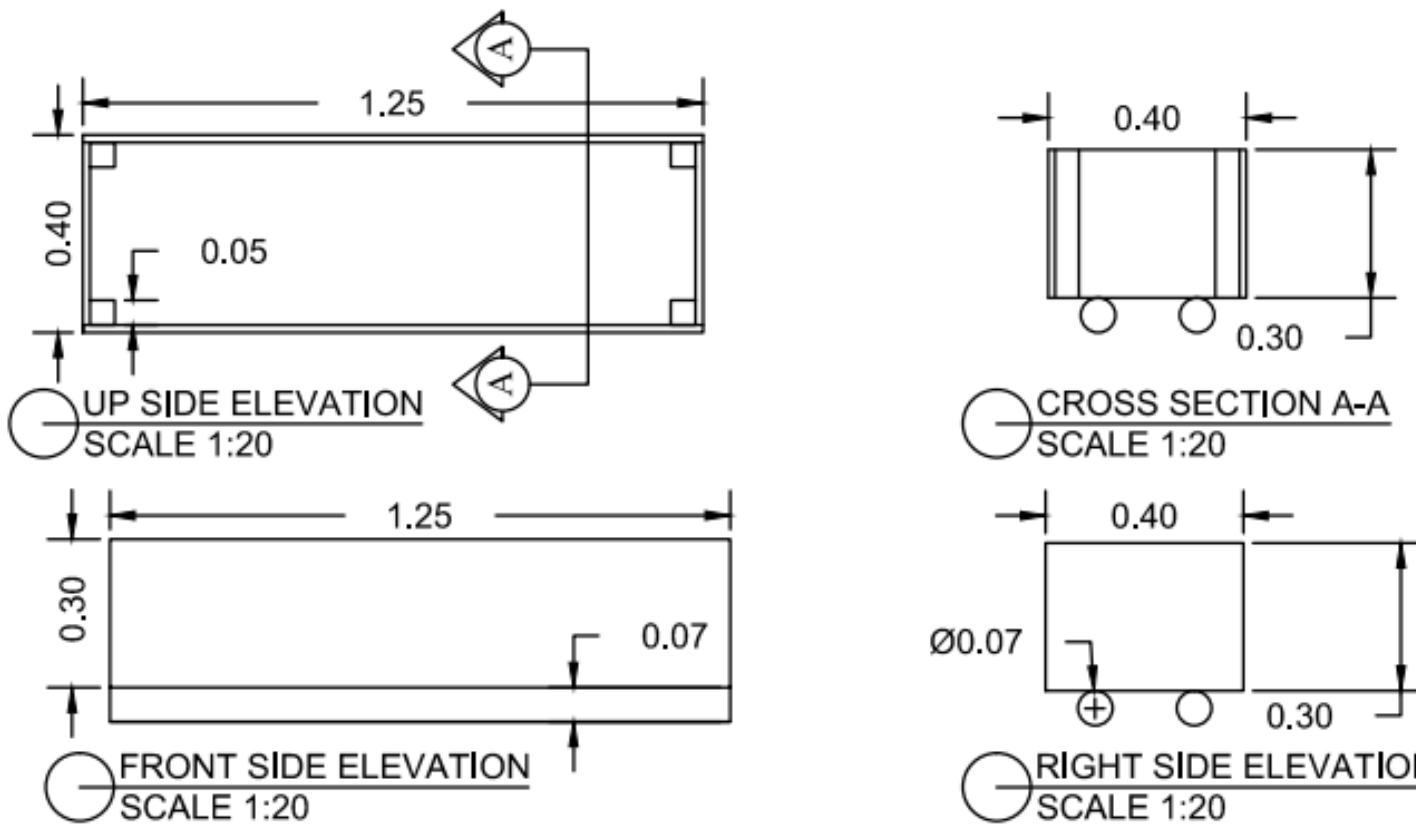

Appendix 1:-Detail of composting bin 


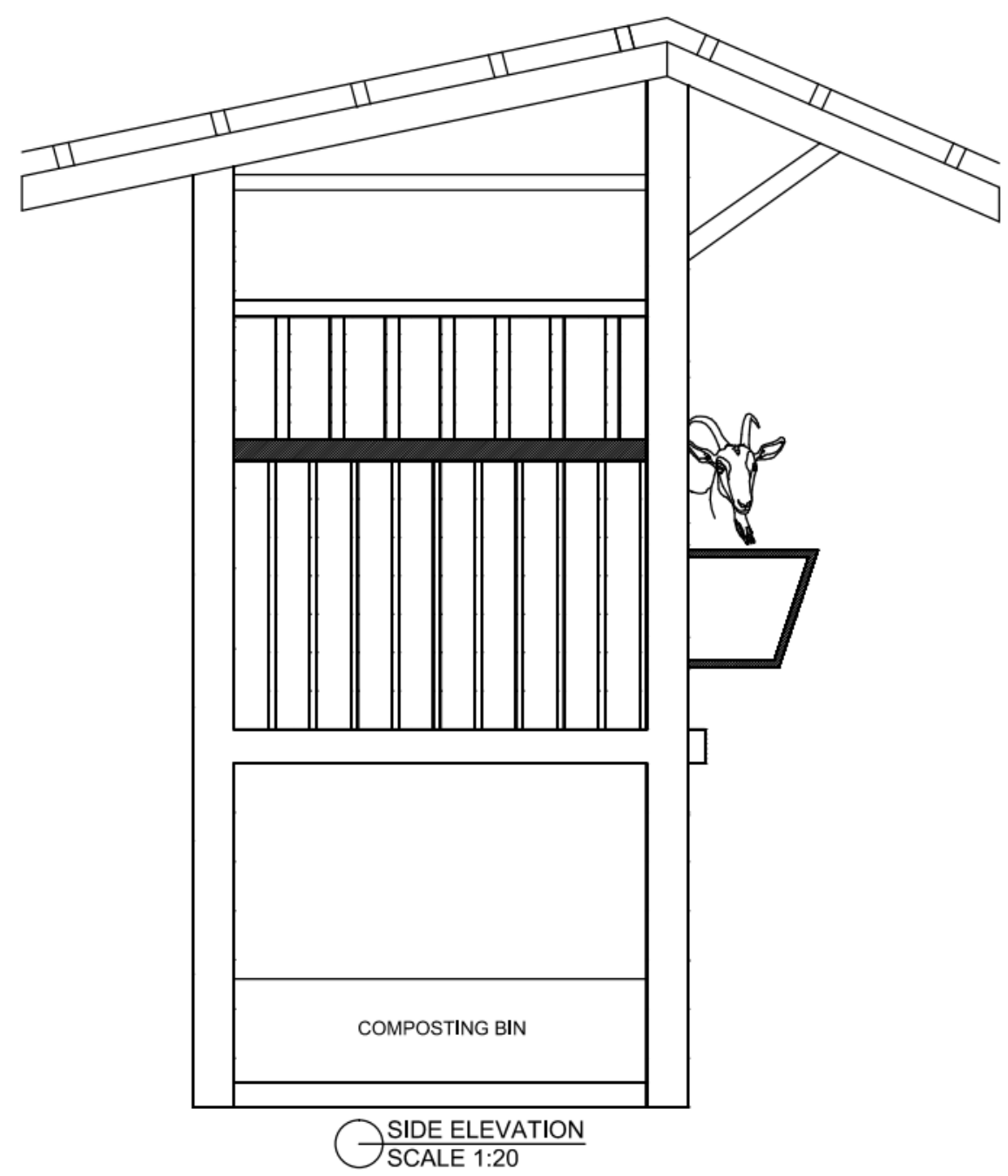

Appendix 2:-On-farm composting package 

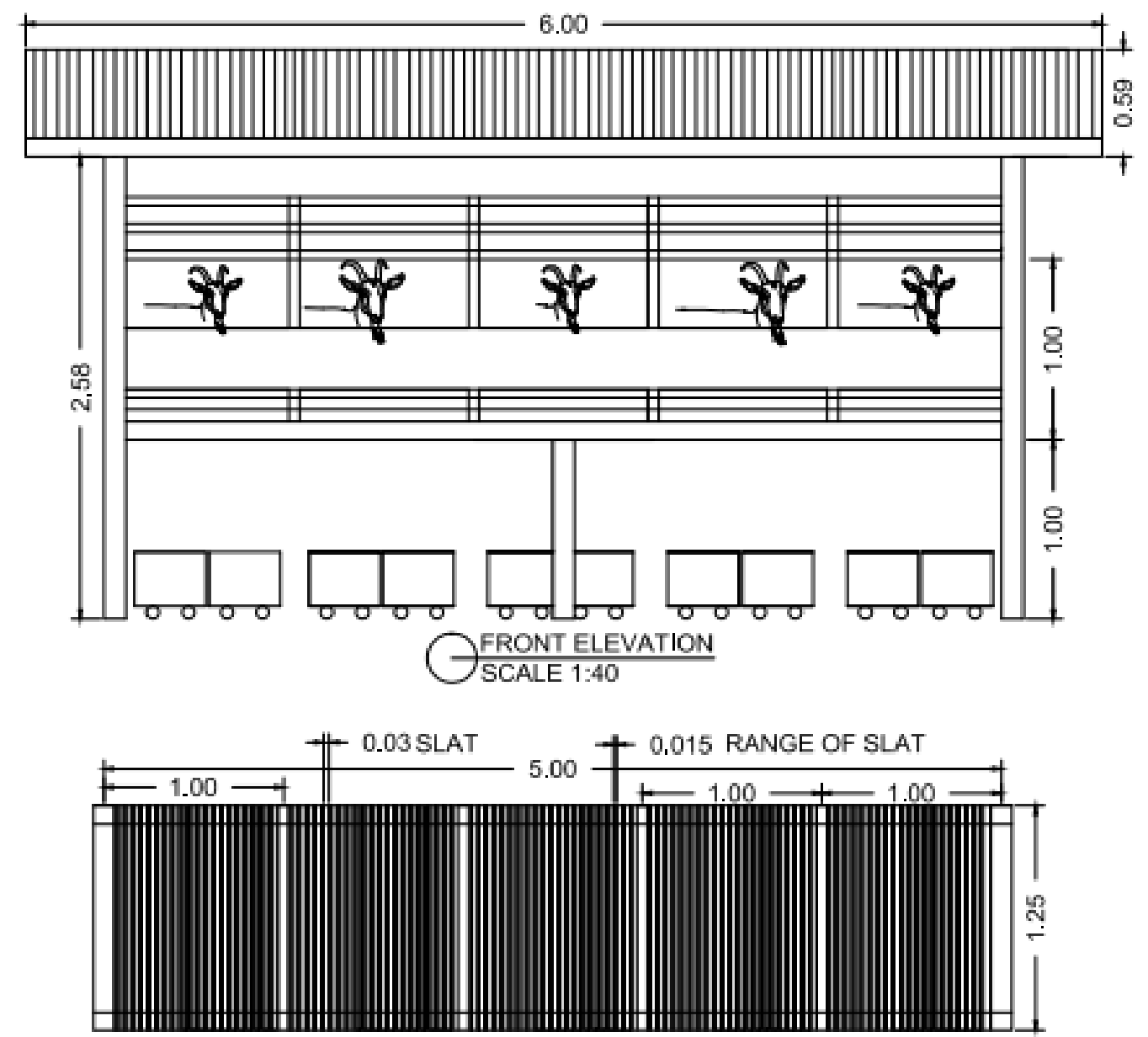

$\overbrace{\text { SCALE } 1: 40}^{\text {FLOOR OF SLATTED }}$

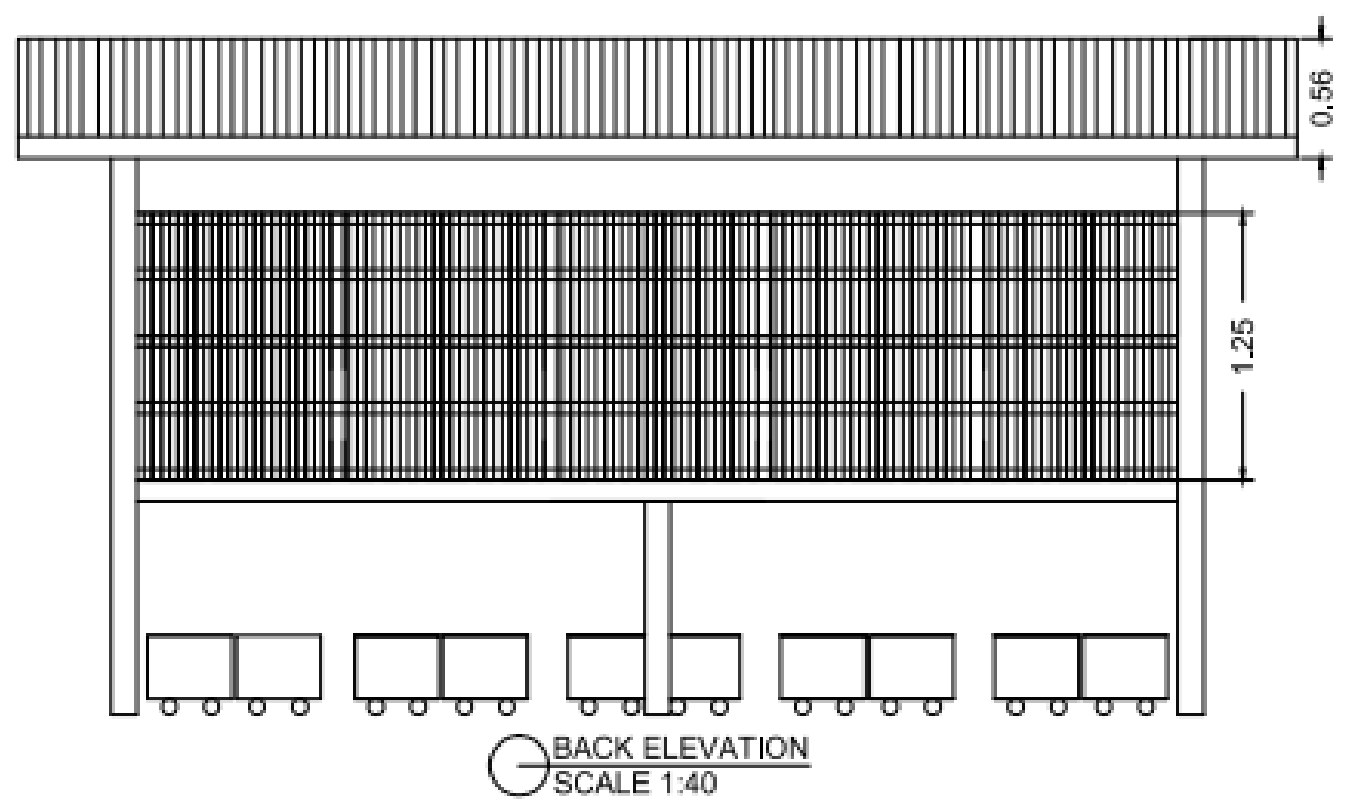

Appendix 3:-Detail of goat housing with raised slatted floor 


\section{Design of on-farm composting package:-}

The on-farm composting package comprises goat housing with raised slatted floor and composting bin. The housing was designed for 5 goats with reference to the rules of the minister of agriculture Permentan No. 102/2014 about good goats and sheep breeding guidelines. The bin was designed using natural aeratic static pile composting system that its dimension is constructed by considering the ease of removal. There are several bins under the housing. Detail engineering design of the package with drawing software is presented in Appendix.

Raw materials to composting consist of at least 2 mixture with goat manure as the main ones. Another input raw materials should be selected which has a function as a bulking agent to reduce odor emission. In composting process, the manure serves as an activator which increases the decomposition process of organic matter (Novien, 2004).

\section{Conclusions:-}

The conclusions of this research were:

1. On-farm composting package to small farmers consist of:

Goat housing with raised slatted floor and

Composting bin

2. Aerobic composting can be done with low input materials and maintenances.

Materials: goat manure and sawdust

Maintenances: frequent adding sawdust, moving and turning compost pile

3. Majority of the composting product after test performance complied with regulation standard in Indonesia: SNI 19-7030-2004 and Permentan No. 70/2011.

\section{References:-}

1. Augustin, C. and Rahman, S. (2010): Composting animal manures: a guide to the process and management of animal compost. North Dakota (USA). North Dakota State University (NDSU) Extension Service. 1-8.

2. Awasthi, M., K., Pandey, A., K., Khan, J. Bundela, P.S. Wong, J.W.C. and Selvam, A. (2014): Evaluation of thermophilic fungal consortium for organic municipal solid waste composting. Biores. Technol., 168:214-221.

3. Azim, K., Komenane, S., and Soudi, B. (2017): Agro-environmental assessment of composting plants in Southwestern of Morocco (Souss-Massa Region). Int. J. Recycl. Org. Waste Agricult., 6:107.

4. Bernal, M., P., Alburquerque J., A., and Moral, R. (2009): Composting of animal manures and chemical criteria for compost maturity assessment: a review. Biores. Technol., 100:5444-5453.

5. Blazy, V., de Guardia, A., Benoist, J.C. Daumoin, M. Lemasle, M. Wolbert, D. and Barrington, S. (2014): Odorous gaseous emissions as influence by process condition for the forced aeration composting of pig slaughterhouse sludge. Waste Manag., 34(7):1125-1138.

6. Bong, C., P., C., Lim, L., Y., Ho, W.S. Lim, J.S. Klemes, J.J. Towprayoon, S. Ho, C.S. and Lee, C.T. (2017): A review on the global warming potential of cleaner composting and mitigation strategies. J. clean. prod., 146:149-157.

7. [BPS] Badan Pusat Statistik (The Indonesian Central Bureau of Statistics). (2013): Proyeksi Penduduk Indonesia 2010-2035 (Indonesia Population Projection 2010-2035). Jakarta (ID). BPS - Statistics.

8. [BPS] Badan Pusat Statistik (The Indonesian Central Bureau of Statistics). (2016): Statistik produksi kehutanan (Statistics of forestry production). Jakarta (ID). BPS - Statistics.

9. Brito, L., M., Mourão, I., Coutinho, J. and Smith, S.R. (2012): Simple technologies for on-farm composting of cattle slurry solid fraction. Waste Manag., 32:1332-1340.

10. Budisatria, I., G., S., Udo, H., M., J., Eilers, C.H.A.M. Baliarti, E. and van der Zijpp. (2010): Preferences for sheep and goats in Indonesia. Small Rum. Res., 88:16-22.

11. Chadwick, D., Sommer, S., Thorman, R. Fangueiro, D. Cardenas, L. Amon, B. and Misselbrook, T. (2011): Manure management: implications for greenhouse gas emissions. Anim. Feed Sci. Technol., 166-167:514-531.

12. Dangi, M., B., Pretz, C., R., Urynowicz, M.A. Gerow, K.G. and Reddy, J.M. (2011): Municipal solid waste generation in Kathmandu, Nepal. J. Env. Manag., 92(1):240-249.

13. Das, M., Uppal, H., S., Singh, R., Beri, S. Mohan, K.S. Gupta, V.C. and Adholeya, A. (2011): Co-composting of physic nut (Jatropha curcas) deoiled cake with rice straw and different animal dung. Biores. Technol., 102:6541-6546.

14. Davendra, C. (1993): Sustainable animal production from small farm systems in South-East Asia. FAO, Rome (ITA). Anim. Prod. Health., Bull 106. 143 pp. 
15. Dhokhikah, Y. and Trihadiningrum, Y. (2012): Solid waste management in Asian developing countries: challenges and opportunities. J. Appl. Environ. Biol. Sci., 2(7):329-335.

16. EL Kader, N., A., Robin, P., Paillat, J.M. and Leterme, P. (2007): Turning, compacting, and the addition of water as factors affecting gaseous emissions in farm manure composting. Biores. Technol., 98:2619-2628.

17. Fan, Y., V., Lee, C., T., Klemes, J.J. Bong, C.P.C. and Ho, W.S. (2016): Economic assessment system towards sustainable composting quality in the developing countries. Clean Technol. Environ. Policy., 18:2479-2491.

18. Filho, W., L., Brandli, L., Moora, H. Kruopiene, J. and Stenmark, A. (2016): Benchmarking approaches and methods in the field of urban waste management. J. clean prod., 112:4377-4386.

19. Getahun, T., Nigusie, A., Entele, T. Van Gerven, T. and Van der Bruggen, B. (2012): Effect of turning frequencies on composting biodegradable municipal solid waste quality. Resour. Conserv. Recycl., 65:79-84.

20. Grewal, S., K., Rajeev, S., Sreevatsan, S. and Michel, F.C. (2006): Persistence of Mycobacterium avium subsp. paratubercolosis and other zoonotic pathogens during simulated composting, manure packing, and liquid storage of dairy manure. Appl. Environ. Microbiol., 72:565-574.

21. Harir, A., I., Kasim, R., and Ishiyaku, B. (2015): Exploring the resource recovery potentials of municipal solid waste: a review of solid wastes composting in developing countries. IJSRP., 5(4):1-8.

22. Hoornweg, D. and Bhada-Tata, P. (2012): What a waste: a global review of solid waste management. The World Bank.

23. Ince, O., Ozbayram, E., G., Akyol, C. Ince, O. and Ince, B. (2015): Composting practice for sustainable waste management: a case study in Istanbul. Des. Water Treat., 1-5.

24. Iqbal, M., K., Shafiq, T., and Ahmed, K. (2010): Characterization of bulking agents and its effects on physical properties of compost. Biores. Technol., 101:1913-1919.

25. Jara-Samaniego, J., Perez-Murcia, M., D., Bustamante, M.A. Perez-Espinosa, A. Paredes, C. Lopez, M. LopezLluch, D.B. Gavilanes-Teran, I. and Moral, R. (2017): Composting as sustainable strategy for municipal solid waste management in the Chimborazo Region, Ecuador: Suitability of the obtained composts for seedling production. J. clean. prod., 141:1349-1358.

26. Kajiya, Y., Ishii, Y., Fukuyama, K. and Idota, S. (2015): Precise Optimization of poultry manure composting using an experimental small-scale apparatus. J. Biol. Sci., 15(1):40-44.

27. Karak, T., Bhagat, R., M., and Bhattacharyya, P. (2012): Municipal solid waste generation, composition, and management: the world scenario. Crit. Rev. Env. Sci. Technol., 42(15):1509-1630.

28. Kasirivu, J., B., Materechera, S., and Dire, M.M. (2011): Composting ruminant animal manure reduces emergence and species diversity of weed seedlings in a semi-arid environment of South Africa. South African J. Plant Soil., 28(4):228-335.

29. [KKBPRI] Kementerian Koordinator Bidang Perekonomian Republik Indonesia. (2015): Kajian kebijakan dan strategi nasional percepatan pengelolaan persampahan. PT. Arkonin Engineering Manggala Pratama.

30. Leconte, M., C., Mazzarino, M., J., Satti P. and Crego, M.P. (2011): Nitrogen and phosphorus release from poultry manure composts: the role of carbonaceous bulking agents and compost particle sizes. Biol. Fertil. Soils., 47:897-906.

31. Lowder, S., K., Skoet, J., and Raney, T. (2016): The number, size, and distribution of farms, smallholder's farms, and family farms worldwide. World Dev., 87:16-29.

32. MacRae, G. and Rodic, L. (2015): The weak link in waste management in tropical Asia? solid waste collection in Bali. Habitat Int., 50:310-316.

33. Maeda, K., Hanajima, D., Toyoda, S. Yoshida, N. Morioka, R. and Osada, T. (2011): Microbiology of nitrogen cycle in animal manure compost. Microb. Biotechnol,, 4:700-709.

34. Martinez-Blanco, J., Lazcano, C., Christensen, T. Muñoz, P. Rieradevall, J. Moller, J. Anton, A. and Boldrin, A. (2013): Compost benefits for agriculture evaluated by life cycle assessment. A Review. Agronomy for Sustainable Development, Springer Verlag/EDP Sciences/INRA, 2013, 33 (4), pp.721-732. <10.1007/s13593013-0148-7>. <hal-01201397>.

35. Medina, M. (2010): Solid wastes, poverty and the environment in developing country cities challenges and opportunities. Working paper No. 2010/23 UNU-WIDER.

36. Meidiana, C. and Gamse, T. (2010): Development of waste management practices in Indonesia. European J. Sci. Res., 40:199-210.

37. Menikpura, S., N., M., Sang-Arun, J., and Bengtsson, M. (2013): Integrated solid waste management: an approach for enhancing climate co-benefits through resource recovery. J. Clean Prod., 1-9.

38. Michel, F., C., Pecchia, J., A., Rigot, J. and Keener, H.M. (2004): Mass and nutrient losses during the composting of dairy manure amended with sawdust or straw. Compost Sci. Util., 12:323-334.

39. Misra, R., V., Roy, R., N., and Hiraoka, H. (2003): On-farm composting methods. FAO. Rome (ITA). 
40. Mylavarapu, R.S. and Zinati, G.M. (2009): Improvement of soil properties using compost for optimum parsley production in sandy soils. Sci. Hortic., 120:426-430.

41. Ngoc, U.N. and Schnitzer, H. (2009): Sustainable solutions for solid waste management in Southeast Asian countries. Waste, Manag., 29:1982-1995.

42. Novien, A. (2004): Pengaruh beberapa jenis aktivator terhadap kecepatan proses pengomposan dan mutu kompos dari sampah pasar dan pengaruhnya terhadap pertumbuhan dan produksi tanaman Caisim (Brassica juncea L) dan Jagung Semi (Zea mays L) [Skripsi]. Bogor (ID): Institut Pertanian Bogor.

43. Pandyaswargo, A.H. and Premakumara, D.G.J. (2014): Financial sustainability of modern composting: the economically optimal scale for municipal waste composting plant in developing Asia. Int. J. Recycl. Org. Waste Agricult., 3(66):1-14.

44. Peev, B., P., Tasheva, Y., R., Christova-Bagdassarian, V.L. Peev, D.P. and Ahmad, M.A. (2017): Influence on aeration rate on performance characteristics of cattle manure composting with different carbon sources used as bulking agents. IOSR-JAC. 10(11):8-14.

45. [Permentan] Peraturan Menteri Pertanian Republik Indonesia (Regulation of the Minister of Agriculture). (2011): Pupuk organik, pupuk hayati, dan pembenah tanah (Organic fertilizer, Biofertilizer, and soil conditioner). Permentan No.70/2011. Jakarta (ID).

46. [Permentan] Peraturan Menteri Pertanian Republik Indonesia (Regulation of the Minister of Agriculture). (2014): Pedoman pembibitan kambing dan domba yang baik (Good goats and sheep breeding guidelines). Permentan No. 102/2014. Jakarta (ID).

47. Purwanto, D. (2009): Analisa jenis limbah kayu pada industri pengolahan kayu di Kalimantan Selatan (The analysis of variety of wood waste material from wood industry in South Borneo). JRIHH., 1(1):14-20.

48. Righi, S., Oliviera, L., Pedrini, M. Buscaroli, A. and Casa C.D. (2013): Life Cycle Assessment of management systems sewage sludge and food waste: centralized and decentralized approaches. J. clean prod., 44:8-17.

49. Rothenberger, S., Zurbrugg, C., Enayetullah, I. Sinha, A.H.M.M. (2006): Decentralised composting for low and middle income countries, a users' manual. Waste concern., Dhaka [BGD].

50. [SNI] Standar Nasional Indonesia (Indonesian National Standard). (2004): Spesifikasi kompos dari sampah organik domestik (Compost specification from organic domestic waste). SNI 19-7030-2004. Jakarta (ID).

51. Song, Q., Li, J., and Zeng, X. (2014): Minimizing the increasing solid waste through zero waste strategy. J clean prod. 104: 199-210.

52. [ST] Sensus Pertanian (Census of Agriculture). (2013): Laporan hasil sensus pertanian 2013 (pencacahan lengkap) Agricultural census report 2013 (complete enumeration). Jakarta (ID). BPS - Statistics Indonesia.

53. Supaporn, P., Kobayashi, T., and Supawadee, C. (2013): Factors affecting farmers' decisions on utilization of rice straw compost in Northeastern Thailand. JARTS., 114(1):21-27.

54. Viaene, J., Lancker, J., V., Vandecasteele, B. Willekens, K. Bijttebier, J. Ruysschaert, G. De Neve, S. and Reubens, B. (2016): Opportunities and barriers to on-farm composting and compost application: A case study from Northwestern Europe. Waste Manag., 48:181-192.

55. Villar, I., Alves, D., Garrido, J. and Mato, S. (2016): Evolution of microbial dynamics during the maturation phase of the composting of different types of waste. Waste Manag., 54:83-92.

56. Vinneras, B. (2013): Sanitation and hygiene in manure management. In: Sommer SG, Christensen ML, Schmidt T, Jensen LS. Animal manure recycling: treatment and management. Jhon Wiley \& Sons. Page 93104.

57. von Braun, J. (2004): Small-scale farmers in liberalised trade environment. In: Huvio TJ, Kola J, Lundstrom T, editors. Proceeding of the seminar on October 2004. Haiko, Finland. Publication No. 38 Agricultural Policy, Department of Economics and Management, University of Helsinki, Finland. Page 21-52.

58. Wibowo, C. (1990): Pengaruh media semai serbuk gergaji dan pemupukan terhadap pertumbuhan sengon (Paraserianthes falcataria) di Rumah kaca dan di Hutan Pendidikan IPB, Gunung Walat, Sukabumi [Skripsi]. Bogor (ID): Institut Pertanian Bogor.

59. Xiong, Z., Q., Wang, G., X., Huo, Z.C. Yan, L. Gao, Y.M. Wang, Y.J., Gu, J.D. and Wang, W.D. (2017): Effect of aeration rates on the composting processes and nitrogen loss during composting. Appl. Env. Biotech., 2:1-8.

60. Yuwono, A., S., Wirasembada, Y., C., Febrita, J. Sabarina, R.A. and Sefiana, A.D. (2016): Design and performance test of non-odorous and low maintenance (NOL) composting bin prototype. Int. J. Appl. Environ. Sci., 11(5):11991212.

61. Zaman, A.U. (2014): Identification of key assessment indicators of the zero waste management systems. Ecol. Indic., 36:682-693.

62. Zaman, A.U. (2015): A comprehensive review of the development of zero waste management: lessons learned and guidelines. J. Clean Prod., 91:12-25. 